\title{
Present Gas Reserve Estimation Using Wireline Logging Data of Habiganj Gas Field, Bangladesh
}

\author{
Ananna Rahman ${ }^{1,2,3}$, Ashraf Ali Seddique ${ }^{4}$, Md. Hafijur Rahaman Khan ${ }^{1,2,3,}$, Mijanur Rahman \\ ${ }^{1}$ Key Laboratory of Marginal Sea Geology, South China Sea Institute of Oceanology, Chinese Academy of Sciences, Guangzhou, China \\ ${ }^{2}$ University of Chinese Academy of Sciences, Beijing, China \\ ${ }^{3}$ Department of Petroleum and Mining Engineering, Jessore University of Science and Technology, Jessore, Bangladesh \\ ${ }^{4}$ Department of Environmental Science and Engineering, Jatiya Kabi Kazi Nazrul Islam University, Mymensingh, Bangladesh \\ ${ }^{5}$ Bangladesh Petroleum Exploration and Production Company Limited, Dhaka, Bangladesh
}

\section{Email address:}

hrananna02@gmail.com (A. Rahman), aseddique@yahoo.com (A. A. Seddique),mdhrsumon14@gmail.com (Md. H. R. Khan)

${ }^{*}$ Corresponding author

\section{To cite this article:}

Ananna Rahman, Ashraf Ali Seddique, Md. Hafijur Rahaman Khan, Mijanur Rahman. Present Gas Reserve Estimation Using Wireline Logging Data of Habiganj Gas Field, Bangladesh. International Journal of Oil, Gas and Coal Engineering. Vol. 5, No. 7, 2017, pp. 44-50. doi: $10.11648 /$ j.ogce.20170504.12

Received: June 27, 2017; Accepted: July 10, 2017; Published: August 3, 2017

\begin{abstract}
Habiganj Gas Field (HGF) is one of the most producing and promising gas field in Bangladesh which is ranked as second largest gas field in aspects of Gas Initially In Place (GIIP). It formed by a north south elongated anticline which lies in the northernmost end of the $130 \mathrm{~km}$ long Baramura anticline from Tripura (India) in the south. This paper shows the present gas reserve estimation with a view of four gas producing wells (i.e. HBJ-7, HBJ-9, HBJ-10, and HBJ-11) in account of upper gas sand has been access via the investigation of lithology, wire line logging data and production data are used as parameter for volumetric method. The average water and gas saturation of the reservoir has also been determined by Archie equation. From the previous analysis with logging data of HGF, it was found that the Gas Water Contact (GWC) was at $1458 \mathrm{~m}$ and at present it is at about $1415 \mathrm{~m}$. The upper gas sand lies at a depth of $1320 \mathrm{~m}$ below the surface and has a maximum gross pay $230 \mathrm{~m}$ thick. The gas sand shows average porosity $30 \%$ (calculated from the combination of neutron and density porosity logs) and average permeability in the range of 2-4 Darcy's which indicates an excellent quality reservoir. The water saturation of Habiganj gas sand layer is considered for the depth range of $1330 \mathrm{~m}$ to $1510 \mathrm{~m}$ with $5 \mathrm{~m}$ interval in-deed. Thereafter, water saturation and gas saturation of those wells (HBJ-7, HBJ-9, HBJ-10 and HBJ-11) are $27 \%$ and $73 \%, 29 \%$ and $71 \%, 15 \%$ and $85 \%$, and $19 \%$ and $81 \%$ respectively. The gas formation volume factor $\left(\mathrm{B}_{\mathrm{g}}\right)$ is estimated at about $0.0075(\mathrm{rcf} / \mathrm{scf})$ for the average 2053.13psi shut in pressure. From the above discussion it is found that the Gas Initially in Place by HBJ-7, HBJ-9, HBJ-10, and HBJ-11 wells are 5.35Tcf, 4.83Tcf, 5.71Tcf and 5.20Tcf respectively and the cumulative reserve for the HGF is 5.25Tcf while the recoverable reserve is 3.13Tcf. This study would be significant implications for reserve estimation and decision making in an effort to explore the present condition of gas reserve in HGF and the techniques described here can be used in other gas field as a base line for projections of gas reserve.
\end{abstract}

Keywords: Habiganj, Reserve Estimation, Volumetric Method, Porosity, Water Saturation, Gas Saturation

\section{Introduction}

Natural gas is the primary source of energy and power. Like most of the countries natural gas is the primary economic driver of the national economy of Bangladesh. By 2001 , a total of 22 natural gasfields have been discovered in Bangladesh among them two are offshore in the Bay of
Bengal and the rest are located in the eastern onshore areas. The total gas initially in place (GIIP) in these 22 fields is about 26Tcf, of which about 16Tcf is considered recoverable [1]. In 2015 almost 14.16Tcf natural gas reserves were discovered [2]. The gas arises in Miocene-Pliocene age sandstone reservoirs and the depths of about 1,000 to $3,500 \mathrm{~m}$ below the surface. Natural gas from Bangladesh is very pure 
and good quality contains $95 \%$ to $99 \%$ methane, $1.72 \%$ ethane, $0.35 \%$ propane and $0.19 \%$ higher hydrocarbons and almost no or very less amount of sulphur [3].

Habiganj gas field is one of the largest gas producing fields in Bangladesh that was discovered by Pakistan Shell Oil Company in 1963 and it's known as the second biggest gas field in the aspect of GIIP (Proved + Provable). This gas field is now being operated under Bangladesh Gas Field Company Limited (BGFCL) [4]. The gas field area is almost $11 \mathrm{~km}$ long and $4.5 \mathrm{~km}$ wide and well known for excellent quality reservoirs with up to $30 \%$ porosity and several Darcy (2-4darcy) permeability. In Bangladesh now a day, this is one of the major gas producers and 11 wells have been drilled in this structure among them 9 wells drilled in this field are vertical and only 2 wells are deviated type [3]. The first well of Habiganj, HBJ-01 was completed in 1969 in April up to the depth of $3505 \mathrm{~m}$ also encountered two gas bearing reservoir. Both of them the shallow reservoir depth was $1397 \mathrm{~m}$ to $1511.7 \mathrm{~m}$ and the deep reservoir depth was $3014.3 \mathrm{~m}$ to $3037 \mathrm{~m}$ with $114.3 \mathrm{~m}$ thickness. Though the production test was conducted from both zones, the well was completed finally in the shallow gas reservoir because the sand thickness of this zone is better than another zone [14]. Petrobangla re-estimate that the total recoverable gas reserve of this field is 2,787.00 billion cubic feet (bcf) and the Commercial gas production from this field was commenced in 1968 and till December 31, 2016 total 2216.320bcf or $80.99 \%$ percent of reserves has been recovered $[4,5]$.

Many studies have been conducted so far with the intention to estimate the reserve of Habiganj gas field including estimation of 'Hydrocarbon Unit of BangladeshNorwegian Petroleum Directorate (HCU-NPD) (2001)' and 'National Committee for gas demand and reserve (2002)'. However, there is a fluctuation articulated in each estimation due to widely different GIIP and recovery percentage. The present study is devoted to reassess and re-estimate the reserve under a better techno feasible framework to facilitate the reserve settlement dilemma. The revised consequence has been correlated with the other fundamental reserve estimation so as to boost up the precision of the research findings.

Table 1. Field wise Gas reserve of six gas field of BGFCL (BGFCL annual report 2015-2016) [19].

\begin{tabular}{lllll}
\hline Gas Field & Total Reserve (MMCF) & $\begin{array}{l}\text { Extraction up to 30 June, 2016 } \\
\text { (MMCF) }\end{array}$ & \multicolumn{2}{l}{$\begin{array}{l}\text { Remaining Recoverable Reserve } \\
\text { (MMCF) }\end{array}$} \\
\hline Titas & $7,582,000.000$ & $4,174,844.709$ & $3,407,155.291$ & Remaining Reserve (\%) \\
Habiganj & $2,787000.000$ & $2,216,319.566$ & $570,680.434$ & 44.94 \\
Bakhrabad & $1,387,000.000$ & $782,316.092$ & $604,683.908$ & 20.48 \\
Narsingdhi & $345,000.000$ & $174,691.890$ & $170,308.110$ & 43.60 \\
Meghna & $101,000.000$ & $57,637.249$ & $43,362.751$ & 49.36 \\
Kamta & $50,000.000$ & $21,101.000$ & $28,899.000$ & 42.93 \\
Total & $12,252,000.000$ & $7,426.910 .506$ & $4,825,089.494$ & 57.80 \\
\hline
\end{tabular}

[Note: MMCF-Million Cubic Feet]

\section{Location of the Study Area}

Habiganj gas field lies in Madhabpur upazila under Habiganj district some 75 miles north of Dhaka in central of Bangladesh and is located at $24.3750^{\circ} \mathrm{N} 91.4167^{\circ} \mathrm{E}$ (Figure
1). Total area is $2,636.58 \mathrm{~km}^{2}$ and bounded by Sunamganj District to the north, Tripura of India and Maulvibazar District to the east, Balaganj upazila of Sylhet to the northeast, Brahmanbaria and Kishoreganj districts to the west.

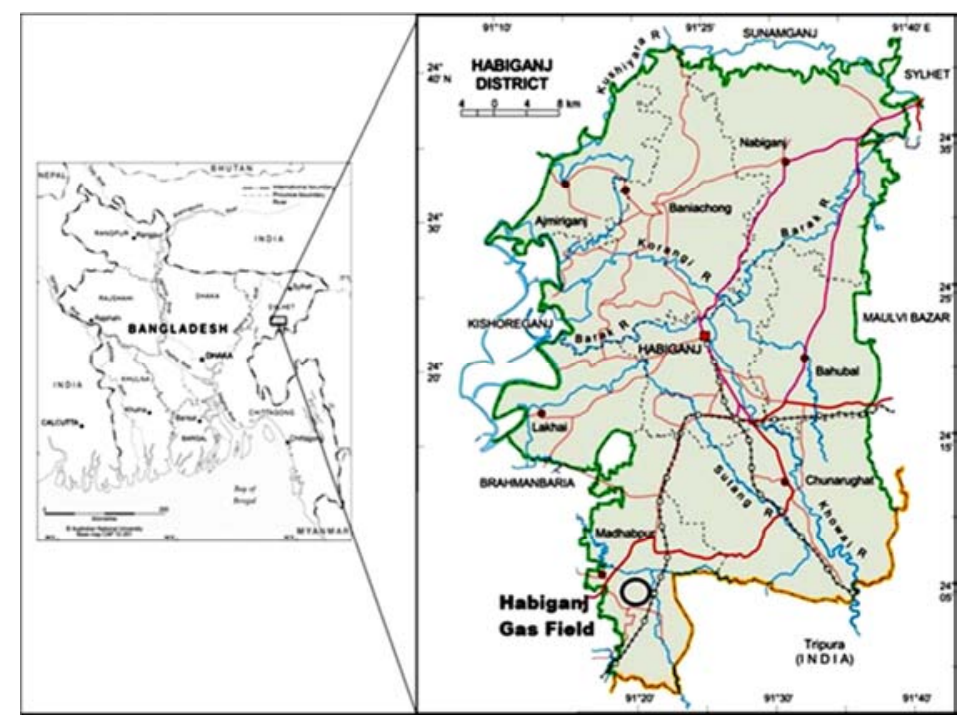

Figure 1. Location map of Habiganj Gas Field, Bangladesh (modified after Australian National University Base map CAP 12-201) [18]. 
In this part of Bangladesh is characterized by alluvial plains which are dissected by various connecting rivers streams, lakes; and it is vulnerable to both flood and drought also the land is devoted mainly to agriculture due to its fertile alluvial soils $[6,7,8]$.

\section{Stratigraphy of the Study Area}

Stratigraphically, Habiganj gas structure is a part of Surma Group which lies in the fold belt east under the subdivision of geosynclinal basin of the structural framework of
Bangladesh. The Surma group is underlying by the Barail group and overlying by the Tipam group. The Barail group is composed of predominantly sandstone, shale and siltstone. The Surma group is composed of alternating sandstone, shale siltstone, conglomerate and clay. The sediments of Surma group are the hydrocarbon kitchen of Bangladesh, where all the hydrocarbon reserves have been accumulated. The Overlying Tipam group is composed of the predominantly sandstone, shale and clay beds [1]. The stratigraphic cross section of the upper gas bearing sandy layer is shown in Figure 2.

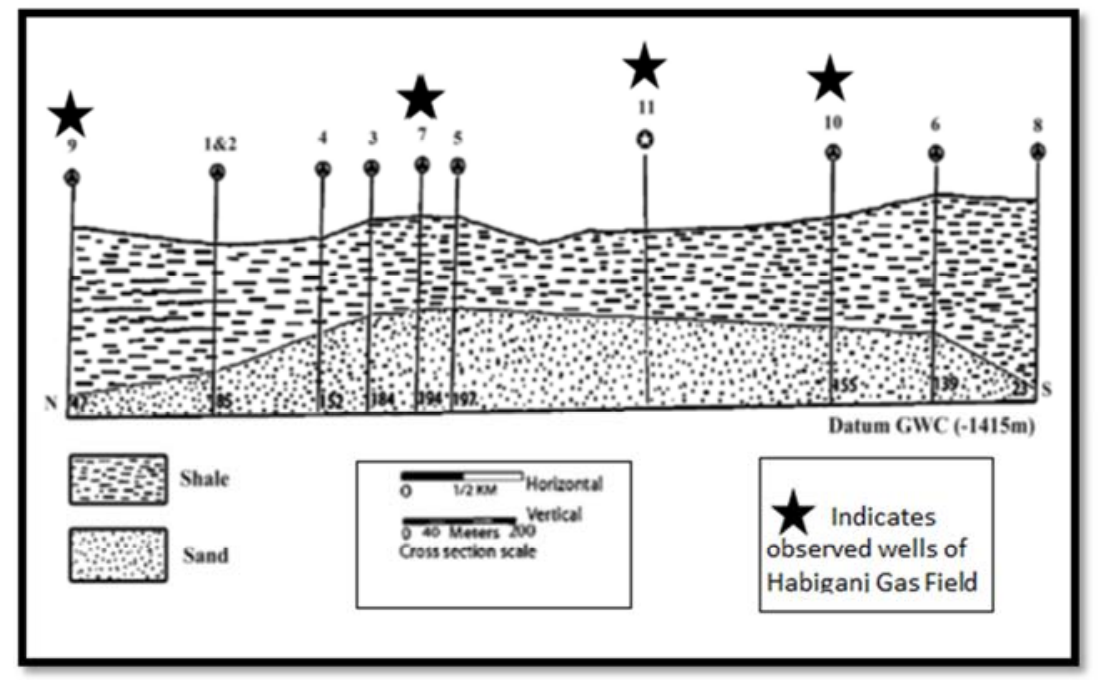

Figure 2. Stratigraphic cross section along N-S, Upper Sand (modified after BGFCL-2009) [4].

\section{Materials and Methods}

Wireline logging data is the fundamental tool to determine the quantity of reserve using volumetric estimation method also it helps to define physical characteristics of the reservoirs such as porosity, saturation, hydrocarbon movability, water saturation, hydrocarbon saturation, gas water contact (GWC) and permeability [10]. Wireline logging data basically includes resistivity, gamma ray, sonic, neutron and density logs and this logs are the elementary tool for identifying permeable zones for hydrocarbon with depth and thickness of the zones and to distinguish the boundaries of oil, gas or water in a reservoir. For estimating the reserve of a hydrocarbon reservoir this logs are very important [15].

In this research work, depth counter map of upper gas sand (UGS) of Habiganj gas field was considered to estimate the aerial coverage of the gas structure. Thickness of the UGS was calculated by averaging the thickness of net gas in feet resulted from individual 11 wells. Porosity of the UGS was calculated from the neutron and density logs. The wireline log data was needed to calculate the hydrocarbon saturation of the Habiganj gas field which was taken from Bangladesh Gas Field Company Limited (BGFCL). The gas formation volume factor $\left(\mathrm{B}_{\mathrm{g}}\right)$ was calculated from the production data using standing-katz diagram. There are many interpretation techniques have been used to detect hydrocarbon-bearing zones and also to estimate their porosities and fluid saturations but the optimum interpretation technique for analyzing a formation of interest depends on the quantity and the quality of the data available to the log analyst [16].

In volumetric method estimated rock volume of the reservoir is multiplied with porosity and gas saturation to calculate the gas in place. Although the calculation procedure is very simple, important consideration is the uncertainty associated with the data used. Volumetric methods are used early in the life of the reservoir before any significant production and development activities. Obviously early in the production life of a reservoir when few data are available to establish the subsurface geologic control, volumetric estimates are least accurate [13]. Accuracy of volumetric estimates however increases with production and development activities, as more data become available.

In this research work, the volumetric method has been used for reserve calculation. The typical volumetric estimation formula used in this research work is given as below:

Gas Initially In Place $(\mathrm{GIIP})=\mathrm{A} \times \mathrm{h} \times \phi \times\left(1 / \mathrm{B}_{\mathrm{g}}\right) \times\left(1-\mathrm{S}_{\mathrm{w}}\right)$

Where,

$\mathrm{A}=$ Area in Acre (From contour map)

$\mathrm{h}=$ Average Thickness in Feet (net sand)

$43560=$ Conversion Factor (From acre to cubic feet) 
$\phi=$ Average Porosity

$\mathrm{B}_{\mathrm{g}}=$ Gas Formation Volume Factor (0.0075 rcf/scf) [4]

$\mathrm{S}_{\mathrm{w}}=$ Water Saturation

\section{Results and Discussions}

Areal extension, thickness, porosity, water saturation, Hydrocarbon saturation and formation volume factor are the basic parameters of initial reserve estimation. Planning of a well trajectory depends on these parameters and also the total production life of that corresponding well. Some of these parameters (rock volume, aerial thickness, porosity, hydrocarbon saturation) have been put to the volumetric estimation calculation as they serve as raw data from reliable source (BGFCL) and rest of the parameters are taken from the recognized open literature.

\subsection{Rock Volume}

The rock volume generally describes the multiplication of the aerial extension and thickness of the reservoir sand layer. The aerial extension of Habiganj gas field is being calculated by using the depth contour map of upper gas sand. The depth contour map is being plotted to the $(20 \mathrm{~cm} \times 25 \mathrm{~cm})$ graphical paper. Then we have been counted the least square value in mm scale which was covered by the depth counter map on the graph paper. Accumulation of the least square value gives the true value of the aerial extension. Aerial extension of upper gas sand has been calculated both for the initial gas water contact and present gas water contact. The aerial coverage for the Initial Gas Water Contact (IGWC) is 3600 sq. mm. and for the present gas water contact (PGWC) is 2300 sq. mm. in case of Habiganj gas field upper gas sand for $\mathrm{HBJ}-7,9,10$ and 11 respectively.

\subsection{Thickness}

A total no. of 11 wells has been drilled in the Habiganj gas structure so far. Thickness of net gas in respect of those wells possesses a varying value ranging from 77 feet to 646 feet. Habiganj gas structure having an average net gas thickness of 412.55 feet. Table 2 shows the thickness of net gas bearing sandy layer in respect of all individual wells.

Table 2. Thickness of net gas considering all the 11 wells (BGFCL, 2009) [4].

\begin{tabular}{llll}
\hline Well No. & GWC (current) & $\begin{array}{l}\text { Thickness of net } \\
\text { gas (meter) }\end{array}$ & $\begin{array}{l}\text { Thickness of net } \\
\text { gas (feet) }\end{array}$ \\
\hline 01 & -1458.00 & 85.00 & 279 \\
02 & -1458.00 & 85.00 & 279 \\
03 & -1456.50 & 189.00 & 620 \\
04 & -1454.00 & 151.00 & 495 \\
05 & -1455.00 & 197.00 & 646 \\
06 & -1454.00 & 139.00 & 458 \\
07 & -1458.19 & 194.00 & 638 \\
08 & -1458.00 & 23.00 & 77 \\
09 & -1450.50 & 47.50 & 156 \\
10 & -1463.60 & 155.00 & 508 \\
11 & -1415.00 & 116.50 & 382 \\
\hline
\end{tabular}

[GWC- Gas Water Contact]

\subsection{Porosity}

The net thickness of gas bearing sandstone layer encountered in this research work is about $192 \mathrm{~m}$. The gas sand layer is typically medium to fine grained, well sorted, clean, unconsolidated and uncompacted in nature belonging to the Surma group of Miocene-Pliocene age [1]. The average porosity $(\phi)$ of Habiganj gas bearing sandstone is calculated from the combination of neutron and density porosity logs. The neutron porosity log indicates the formation hydrogen index (HI) [9]. The neutron porosity log alternatively measures the formation water content. The average neutron porosity $\left(\varphi_{n}\right)$ of gas sand layer is about 0.39 which is high compared to other gas fields of Bangladesh [1]. The density porosity log indicates the formations bulk density which is used to calculate the formation porosity. The average Density porosity $\left(\varphi_{d}\right)$ of gas sand layer is about 0.25 , which ensures the Habiganj gas field as an excellent quality reservoir. The average porosity of Habiganj gas bearing layer is estimated which about 0.30 or $30 \%$ from the empirical formula is given below:

$$
\phi=\sqrt{ }\left[\left(\varphi_{\mathrm{n}}^{2}+\varphi_{\mathrm{d}}^{2}\right) / 2\right]
$$

\subsection{Water and Gas Saturation}

The sandstone material of Habiganj gas field is essentially insulator and the enclosed hydrocarbon is infinitely resistive in nature. Basically resistivity is a function of formation water saturation $\left(\mathrm{S}_{\mathrm{w}}\right)$. The water saturation of Habiganj gas sand layer is considered for the depth range of $1330 \mathrm{~m}$ to $1510 \mathrm{~m}$ with $5 \mathrm{~m}$ interval in-deed. The water saturation is calculated from the empirical formula of Archie which is illustrated below:

$$
\mathrm{S}_{\mathrm{w}}=\sqrt{ }\left[\left(\mathrm{F} \cdot \mathrm{R}_{\mathrm{w}}\right) / \mathrm{R}_{\mathrm{t}}\right]
$$

Where, $\mathrm{F}=$ Formation Resistivity Factor

$\mathrm{R}_{\mathrm{w}}=$ Resistivity of Formation Water

$\mathrm{R}_{\mathrm{t}}=$ Resistivity of Rock Containing Hydrocarbon

Formation resistivity factor,

$$
\mathrm{F}=\mathrm{a} / \phi^{2}
$$

Where, $\mathrm{a}=0.62$ (for Habiganj gas field) $\phi=$ Porosity of the Reservoir.

Water saturation of wells (HBJ-7, HBJ-9, HBJ-10 and HBJ-11) are $27 \%, 29 \%, 15 \%$, and $19 \%$ respectively The average water saturation of HBJ-07, HBJ-09, HBJ-10 and HBJ-11 for $180 \mathrm{~m}$ thick sand layer is about $22.5 \%$ which may indicate the richness of hydrocarbon bearing formation of Habiganj gas field.

Gas saturations of wells (HBJ-7, HBJ-9, HBJ-10 and HBJ11) are $73 \%, 71 \%, 85 \%$ and $81 \%$ respectively. The average gas saturation of those wells of the Habiganj gas bearing sand layer is about $77.5 \%$ which is calculated from the formula given below:

$$
\mathrm{S}_{\mathrm{hc}}=1-\mathrm{S}_{\mathrm{w}}
$$


Gas water contact of Habiganj sand layer is distinct and typically ellipse in shape both for initial and producing gas water contact boundary. Gas water contact provides the reservoir driving mechanism and in cage of Habiganj it is water drive in-deed. Both resistivity and gamma ray log value is considered for determining gas water contact of reservoir sand. The gas water contact of upper Gas sand of Habiganj recently lies at the depth of about $1415 \mathrm{~m}$ (sub-sea).

\subsection{Gas Formation Volume Factor $\left(B_{g}\right)$}

The gas formation volume factor is essential for estimating the gas initially in place (GIIP). The gas formation volume factor is related with the application of ideal gas law (PV = nRT) and convert surface measured volume to reservoir conditions [11]. The gas formation volume factor is estimated at about $0.0075\left(\mathrm{ft}^{3} / \mathrm{scf}\right)$ for the average 2053.13psi shut in pressure which is calculated from the formula illustrated below. The Z-factor correlation of Standing and Katz diagram is used for the $B_{g}$ estimation [12] which is about 0.834 (dimensionless).

$$
\mathrm{B}_{\mathrm{g}}=\left[\left(0.02827 \times \mathrm{T}_{\mathrm{R}} \times \mathrm{Z}\right) / \mathrm{P}_{\mathrm{R}}\right]
$$

Where, $\mathrm{T}_{\mathrm{R}}=$ Reservoir Temperature

$$
\mathrm{P}_{\mathrm{R}}=\text { Reservoir Pressure }
$$

$\mathrm{Z}=$ Gas Compressibility Factor $=0.834$ (dimensionless)

\subsection{Over all Calculation of all the Reserve Estimation Properties}

All the measured data of porosity, water saturation, gas saturation and $\mathrm{Bg}$ of respective wells (HBJ-07, HBJ-09, HBJ10 and HBJ-11) are showing as follows in the table:

Table 3. Average porosity, water saturation, gas saturation and Bg of HBJ-07, HBJ-09, HBJ-10 and HBJ-11.

\begin{tabular}{lllll}
\hline Well no. & $\begin{array}{l}\text { Average porosity } \\
\boldsymbol{\phi}=\sqrt{ }\left[\left(\boldsymbol{\varphi}_{\boldsymbol{n}}^{2}+\boldsymbol{\varphi}_{\boldsymbol{d}}^{\mathbf{2}}\right) / \mathbf{2}\right]\end{array}$ & $\begin{array}{l}\text { Average water saturation } \\
\mathbf{S}_{\mathbf{w}}=\sqrt{\left[\left(\mathbf{F} . \mathbf{R}_{\mathbf{w}}\right) / \mathbf{R}_{\mathbf{t}}\right]}\end{array}$ & $\begin{array}{l}\text { Average gas saturation } \\
\boldsymbol{S}_{\boldsymbol{h} \boldsymbol{c}}=\mathbf{1 - \boldsymbol { S } _ { \boldsymbol { w } }}\end{array}$ \\
\hline HBJ-07 & 0.31 & 0.27 & 0.73 & 0.0075 \\
HBJ-09 & 0.33 & 0.29 & 0.71 & 0.0075 \\
HBJ-10 & 0.326 & 0.15 & 0.85 & 0.0075 \\
HBJ-11 & 0.31 & 0.19 & 0.81 & 0.0075 \\
\hline
\end{tabular}

\subsection{Gas Initially In Place (GIIP)}

According to the volumetric method equation (Equation 1) the GIIP has been estimated both for initial gas water contact (IGWC) and present gas water contact (PGWC) in respect of upper gas sand.

(i) Habiganj well no. 07

For Initially Gas Water Contact (IGWC).

$$
\begin{aligned}
\mathrm{GIIP} & =\mathrm{A} \times \mathrm{h} \times \phi \times\left(1 / \mathrm{B}_{\mathrm{g}}\right) \times\left(1-\mathrm{S}_{\mathrm{w}}\right) \\
& =3500 \times 10.71 \times 10000 \times 412.55 \times 0.31 \times 0.73 \times(1 / 0.0075) \\
& =5.35 \mathrm{Tcf}
\end{aligned}
$$

For Present Gas Water Contact (PGWC).

$$
\begin{aligned}
\mathrm{GIIP} & =\mathrm{A} \times \mathrm{h} \times \phi \times\left(1 / \mathrm{B}_{\mathrm{g}}\right) \times\left(1-\mathrm{S}_{\mathrm{w}}\right) \\
& =2300 \times 10.71 \times 10000 \times 412.55 \times 0.31 \times 0.73 \times(1 / 0.0075) \\
& =3.07 \mathrm{Tcf}
\end{aligned}
$$

(ii) Habiganj well no. 09

For Initially Gas Water Contact (IGWC).

$$
\begin{aligned}
\mathrm{GIIP} & =\mathrm{A} \times \mathrm{h} \times \phi \times\left(1 / \mathrm{B}_{\mathrm{g}}\right) \times\left(1-\mathrm{S}_{\mathrm{w}}\right) \\
& =3500 \times 10.71 \times 10000 \times 412.55 \times 0.33 \times 0.71 \times(1 / 0.0075) \\
& =4.83 \mathrm{Tcf}
\end{aligned}
$$

For Present Gas Water Contact (PGWC).

$$
\begin{aligned}
\mathrm{GIIP} & =\mathrm{A} \times \mathrm{h} \times \phi \times\left(1 / \mathrm{B}_{\mathrm{g}}\right) \times\left(1-\mathrm{S}_{\mathrm{w}}\right) \\
& =2300 \times 10.71 \times 10000 \times 412.55 \times 0.33 \times 0.71 \times(1 / 0.0075) \\
& =3.17 \mathrm{Tcf}
\end{aligned}
$$

(iii) Habiganj well no. 10

For Initially Gas Water Contact (IGWC).

$$
\begin{aligned}
\mathrm{GIIP} & =\mathrm{A} \times \mathrm{h} \times \phi \times\left(1 / \mathrm{B}_{\mathrm{g}}\right) \times\left(1-\mathrm{S}_{\mathrm{w}}\right) \\
& =3500 \times 10.71 \times 10000 \times 412.55 \times 0.326 \times 0.85 \times(1 / 0.0075) \\
& =5.71 \mathrm{Tcf}
\end{aligned}
$$

For Present Gas Water Contact (PGWC).

$$
\begin{aligned}
\mathrm{GIIP} & =\mathrm{A} \times \mathrm{h} \times \phi \times\left(1 / \mathrm{B}_{\mathrm{g}}\right) \times\left(1-\mathrm{S}_{\mathrm{w}}\right) \\
& =2300 \times 10.71 \times 10000 \times 412.55 \times 0.326 \times 0.85 \times(1 / 0.0075) \\
& =3.75 \mathrm{Tcf}
\end{aligned}
$$

(iv) Habiganj well no. 11

For Initially Gas Water Contact (IGWC).

$$
\begin{aligned}
\mathrm{GIIP} & =\mathrm{A} \times \mathrm{h} \times \phi \times\left(1 / \mathrm{B}_{\mathrm{g}}\right) \times\left(1-\mathrm{S}_{\mathrm{w}}\right) \\
& =3500 \times 10.71 \times 10000 \times 412.55 \times 0.31 \times 0.81 \times(1 / 0.0075) \\
& =5.20 \mathrm{Tcf}
\end{aligned}
$$

For Present Gas Water Contact (PGWC).

$$
\begin{aligned}
\mathrm{GIIP} & =\mathrm{A} \times \mathrm{h} \times \phi \times\left(1 / \mathrm{B}_{\mathrm{g}}\right) \times\left(1-\mathrm{S}_{\mathrm{w}}\right) \\
& =2300 \times 10.71 \times 10000 \times 412.55 \times 0.31 \times 0.81 \times(1 / 0.0075) \\
& =3.40 \mathrm{Tcf}
\end{aligned}
$$


Table 4. Correlation the reserve estimation data with production data.

\begin{tabular}{llll}
\hline Well No. & Initial Reserve (Tcf) & Present Reserve (Tcf) & Produced Reserve (Tef) \\
\hline HBJ-07 & 5.35 & 3.07 & 2.28 \\
HBJ-09 & 4.83 & 3,17 & 1.66 \\
HBJ-10 & 5.71 & 3.75 & 1.96 \\
HBJ-11 & 5.20 & 3.40 & 1.8 \\
& Total $=5.3$ & Total $=3.13$ & Total $=1.93$ \\
\hline
\end{tabular}

[Note: Tcf-Trillion Cubic Feet]

Table 5. Correlation of this study's resulst with the previous estimated reserve (Tcf) [4, 17].

\begin{tabular}{|c|c|c|c|c|c|c|c|c|}
\hline \multirow[t]{2}{*}{ Gas Field } & \multicolumn{2}{|c|}{ IKM (1992) } & \multicolumn{2}{|c|}{ HCU-NPD (2001) } & \multicolumn{2}{|c|}{ Petrobangla (2012) } & \multicolumn{2}{|c|}{ Present Study } \\
\hline & GIIP & $\begin{array}{l}\text { Recoverable } \\
\text { Reserve (Initial) }\end{array}$ & GIIP & $\begin{array}{l}\text { Recoverable } \\
\text { Reserve (Initial) }\end{array}$ & GIIP & $\begin{array}{l}\text { Recoverable } \\
\text { Reserve (Initial) }\end{array}$ & GIIP & $\begin{array}{l}\text { Recoverable } \\
\text { Reserve (Initial) }\end{array}$ \\
\hline $\begin{array}{l}\text { Habiganj Gas } \\
\text { Field }\end{array}$ & 3.66 & 1.89 & 5.13 & 3.85 & 3.68 & 2.83 & $\begin{array}{l}5.35 \\
\text { (HBJ-07) } \\
4.83 \\
(\mathrm{HBJ}-09) \\
5.71 \\
(\mathrm{HBJ}-10) \\
5.20 \\
(\mathrm{HBJ}-11) \\
\text { Total }=5.3\end{array}$ & 3.13 \\
\hline
\end{tabular}

[Note: IKM-Intercomp-Kamta Management Limited; HCU-NPD-Hydrocarbon Unit of Bangladesh-Norwegian Petroleum Directorate; GIIP- Gas Initially In place; Tcf-Trillion Cubic Feet]

\section{Conclusion}

Reserve estimation in a gas reservoir is a very complex procedure and in most of the case gas reservoirs are associated with some heterogeneity. Though the data was not so sufficient to calculate a reservoir like Habiganj Gas field which is a very large and excellent gas reservoir in Bangladesh.

In a previous study conducted by Bangladesh Gas Field Company Ltd. (BGFCL) revealed that the upper gas sand starts from $1263.19 \mathrm{~m}$ (Sub-sea) and it continues up to gas water contact at $1458.19 \mathrm{~m}$ (sub-sea). On the other hand, another study conducted by Intercomp-Kamta Management Ltd. [17] indicated that the upper gas pool has an optimum column between $1250 \mathrm{~m}$ (sub-sea) to $149345 \mathrm{~m}$ (sub-sea). The above two reports generally support the log derived depth of upper gas sand [10].

From the present study of Habiganj well-07, 09, 10 and 11, the $\log$ derived average neutron porosity are estimated at $23.68 \%, 20.5 \%, 17 \%$ and $17 \%$ respectively whereas the density porosity $\log$ are determined at $39.03 \%$. $40.24 \%$, $41.10 \%$ and $40 \%$ for the above mentioned wells successively. The combination of neutron density porosity in respect of Habiganj well- 07, 09, 10 and 11 are estimated at 0.31, 0.33, 0.326 and 0.31 . The previous production tests in the upper gas sand reveal that the average porosity in Habiganj gas field is in range of 0.30 .

In this research work the average water saturation calculated on the basis of wireline log data of upper gas sand are $0.17,0.29,0.15$ and 0.19 for well- $07,09,10$ and 11 and the hydrocarbon saturation of those wells are $0.73,0.71 .0 .85$ and 0.81 . The previous study indicated that the water saturation is 0.28 and hydrocarbon saturation is 0.72 for the
Habiganj gas field [10]. The above discussion suggests that the water saturation and hydrocarbon saturation value determined in the present study from wireline $\log$ and previous study generally match with each other. The result of volumetric calculation shows that the cumulative initial GIIP of Habiganj well-07, 09, 10 and 11 is about 5.35Tcf, and present GIIP is about 3.13 Tcf. About 1.93Tcf gas has been produced, which is matching with production data. At the present situation, there would be some recommendation on some points,

1. The field recovery factor should be properly calculated.

2. The remaining $1.93 \mathrm{Tcf}$ gas may be produced from the upper gas sand to meet the country's future energy demand. There is a scope to install a recovery well between Habiganj well-10 and well-11 in order to enhance the gas production from the respective upper gas bearing sand. The relevant data and present production data are necessary to make accuracy while calculating by volumetric methods.

\section{References}

[1] Imam B. (2005). Energy Resources of Bangladesh. Published by University Grants Commission of Bangladesh, Dhaka, 2005, pp 280.

[2] Gas reserve to last until 2031. The Daily Star. 28 June 2015. (February 3, 2016).

[3] Gas, Natural - Banglapedia (May 3, 2017).

[4] BGFCL Annual Report. (2009). Reserve (HCU) of Different Gas Fields under Bangladesh Gas Field Company Limited (BGFCL), published in Reservoir Engineering Section. 
[5] www.bgfcl.org.bd/habiganj gas field. (May 12, 2017).

[6] Roy J. S. (2012). "Habiganj District" In Sirajul Islam and Ahmed A. Jamal. Banglapedia: National Encyclopedia of Bangladesh (Second ed.). Asiatic Society of Bangladesh.

[7] Alam M. S. (2002). Gas-in-place Estimate of the Habiganj Gas Field Using Material Balance, A thesis of Masters, Department of Petroleum and Mineral Resources Engineering, University of Engineering and Technology, Bangladesh. 93 p.

[8] Shofiqul M. I. and Nusrat J. B. (2013). Reservoir characterization of Habiganj gas field, International Journal of Oil, Gas and Coal Engineering. Vol. 1, No. 1, 2013, pp. 7-15. doi: 10.11648/j.ogce.20130101. 12.

[9] Rider M. H. and Kennedy M. (1996). The Geological interpretation of well logs, second edition, Caithness, Scotland: Whittles, $280 \mathrm{p}$.

[10] Reza A., Islam M. T. and Islam M. A. (2014). Evaluation of Gas Reservoir of the Meghna Gas Field, Bangladesh Using Wireline Log Interpretation, Universal Journal of Geoscience 2 (2): 62-69, 2014, DOI: 10.13189/ujg.2014. 020204.

[11] Economides and Michael J. (1994). Petroleum Production Systems, Published by Prentice Hall Inc, New Jersey 07458, $67 \mathrm{p}$.

[12] Ikoku and Chiu (1984). Natural Gas Production Engineering, Published by KRIEGER publishing Company Malabar, Florida, 39p and $59 \mathrm{p}$.
[13] Lee W. J. and Wattenbarger R. A. (1996). Gas Reservoir Engineering, SPE.

[14] Nawab M. M., and Hossain M. S. (2010). The Effect of Water Influx on Material Balance Analysis for Water Drive Gas Reservoir: A Case Study on Habiganj Gas Field, Bangladesh, Bangladesh Geoscience Journal, v. 16, p. 69-84.

[15] Islam A. R. M. T, Habib M. A, Islam M. T. and Mita M. R (2013). Interpretation of wireline $\log$ data for reservoir characterization of the Rashidpur Gas Field, Bengal Basin, Bangladesh, IOSR Journal of Applied Geology and Geophysics (IOSR-JAGG), e-ISSN: 2321-0990, p-ISSN: 2321-0982. Volume 1, Issue 4 (Sep. - Oct. 2013), PP 47-54.

[16] Hai M. A., Ahammod S., Faruque M. O., Hussain M. A. and Ahmed J. (2014). Identification and determination of gross thickness of hydrocarbon bearing zone of Habiganj gas field, American Journal of Engineering Research (AJER) e-ISSN: 2320-0847 p-ISSN: 2320-0936 Volume-3, Issue-8, pp-79-89.

[17] Haq M. B. and Rahman M. K. (2008). A Comparative Study of Three Methods for Estimating Initial Gas-in-place in Gas Fields in Bangladesh, Petroleum Science and Technology, Volume 26, 2008 - Issue 5, Pages 532-544.

[18] Australian National University Bangladesh Base Map CAP 12-201, 3 March 2017.

[19] Annual Report (2015-16). Bangladesh Gas Field Company Limited (BGFCL), http://www.bgfcl.org.bd., (March 03, 2016). 